\title{
* *mangryon
}

Title: Embracing the Event Portfolio Paradigm in Academic Discourse and Scholarship

Author(s): Vassilios Ziakis

Copyright, publisher and additional information: This is an Accepted Manuscript of an article published by Taylor \& Francis in Journal of Policy Research in Tourism, Leisure and Events on $10^{\text {th }}$ February 2019 available online:

https://www.tandfonline.com/doi/full/10.1080/19407963.2018.1556861

DOI: $10.1080 / 19407963.2018 .1556861$

Reference: Ziakas, V. (2019). Embracing the event portfolio paradigm in academic discourse and scholarship, Journal of Policy Research in Tourism, Leisure and

Events, 11(sup1), 27-33, DOI: 10.1080/19407963.2018.1556861 


\section{Embracing the Event Portfolio Paradigm in Academic Discourse and Scholarship Vassilios Ziakas \\ Plymouth Marjon University}

\section{Prologue: A Growing Seed}

There has been almost a decade since the publication of the first empirical study (Ziakas, 2010), here in Journal of Policy Research in Tourism, Leisure and Events, examining the emergent phenomenon of event portfolio. This article received quickly positive response and is now the most downloaded in the journal, planting thus a seed for undertaking further research on the embryonic field of event portfolio management. Indeed, since its publication, a small pile of literature has emerged following this line of inquiry that focuses, instead of single events, on portfolios comprising an array of interrelated events. This literature includes portfolio studies on Gainesville, Florida (Gibson, Kaplanidou, \& Kang, 2012), Termoli in Italy (Presenza \& Sheehan, 2013), London, Ontario (Clark \& Misener, 2015), Portimão in Portugal (Pereira, Mascarenhas, Flores, \& Pires, 2015), Barcelona (Richards, 2015), Sunshine Coast in Australia (Gration, Raciti, Getz, \& Andersson, 2016), Auckland in New Zealand (Antchak, 2017), Berlin (Viol, Todd, Theodoraki, \& Anastasiadou, 2018), and Cook Islands (Dickson, Milne, \& Werner, 2018). Further, portfolio-related aspects, approaches and issues were examined (Andersson, Getz, \& Mykletun, 2013; Andersson, Getz, Gration, \& Raciti, 2017; Antchak \& Pernecky, 2017; Dragin-Jensen, Schnittka, \& Arkil, 2016; Kelly \& Fairley, 2018; Sanders, Laing, \& Frost, 2015; Taks et al., 2009; Westerbeek \& Linley, 2012; Ziakas \& Boukas, 2016). Evidently, therefore, the seed has grown but the fruits are thin on the ground and not ready for harvesting. 
In fact, the above limited literature that has come to light, falls short in addressing the remarkably growing investment of cities and regions worldwide in developing their calendar events program and thus designing compound portfolios. There are several reasons for this academic tardiness, with the main one concerning the innate fragmentation of the events sector and the different disciplinary concentrations (i.e., cultural, business and sport events) that constrain the adoption of a holistic approach on planned events. For example, the predominant specializations on festivals, MICE (meetings, incentives, conventions and expos) and sport events continue to be treated by academics more as separate domains serving their respective disciplinary agendas rather than as interdependent and complementary realms.

In parallel, the phenomenon of event portfolio as a policy tool has largely received approval and recognition worldwide (Antchack \& Pernecky, 2017; Getz, 2013; Getz \& Page, 2016; Richards \& Palmer, 2010; Ziakas, 2014a). For example, the cities of Edinburgh (City of Edinburgh, 2007), Gold Coast (City of Gold Coast, 2011), and Auckland (Auckland Council, 2011) have developed, since 2007 and 2011 their own portfolios. A portfolio approach has also been adopted by regional territories on the national level such as Wales (Welsh Government, 2010) and Scotland (VisitScotland, 2015). In general, the attempt of various destinations to develop event portfolios lies upon the alignment of their event strategies with their policy agendas (Ziakas, 2018). The underlying rationale underpinning portfolio development is to assemble a diversified array of events that take place at different times of the year and that appeal to audiences across the span of consumer profiles to which a host destination seeks to target (Chalip, 2004; Getz, 2013; Ziakas, 2014a). From this standpoint, multiple purposes can be achieved by leveraging the event portfolio and fostering synergies among different events and their stakeholders in order to optimize the overall portfolio benefits and value (Ziakas, 2018; Ziakas \& Costa, 2011a, 2011b). 


\section{The Portfolio Paradigm Shift}

What seems not to have yet been fully understood is that the emergence of event portfolios represents a paradigm shift in the way we treat, study, and manage events. It is not enough anymore to capitalize on single events since their benefits are temporally limited and thus shortlived nor expect sustainable or efficient externalities from mega-events as their costs usually are disproportionately higher. The alternative is to make events a permanent structure in their host community by developing a portfolio of periodic events that comply with local resource capacity and that bestow benefits from one event to another, thereby sustaining and magnifying their overall outcomes. Along these lines, the value of an event portfolio is determined by the efficacy in which an integrated set of resources is used to jointly harness benefits from an array of events taking advantage of their interrelationships and complementarities. At the core of the portfolio paradigm lie the concepts of relatedness and multiplicity. Relatedness in a portfolio refers to the ways that events complement one another, which can occur through capitalization on capacity (know-how), resources, volunteer pools, or markets that might be engendered and maintained by the array of events (Ziakas, 2014a). Multiplicity of an event portfolio refers to its capacity to engender and convey multiple meanings and serve multiple purposes (Ziakas, 2014a).

Consequently, the mission for event managers is to develop strategic capabilities for crossleveraging events with one another in the host community's portfolio in order to maximize intended outcomes. To build portfolio capacity, event managers need to create synergies among different events and allied economic, tourism, leisure, sport, or socio-cultural objectives. This requires a shift in the way events are managed and evaluated. From a portfolio perspective, the 
strategic patterning of events is more than the sum of its parts. This means that we need to view events as parts of a larger system that can generate higher benefits than each event individually. More importantly, each event has its own value and should be given a particular role in contributing to the whole system. Understanding and appreciating portfolios as complex systems that have their own adaptive properties and require managerial acumen is a central avenue of research that needs to be pursued. Event portfolios, if managed effectively, can become robust pillars of a host community's sustainability by bringing continuous benefits through the array of periodic events that meet the triple-bottom-line of economic, social and environmental prosperity.

The potential of event portfolios of course has yet to be proved. As the academic response in studying portfolios has been slow, their substantiation as a significant policy tool will take some time. Pressures from the industry undergoing the growth of portfolios will logically demand more attention on how best to develop and manage portfolios. This brings to the fore the need for higher education institutions to adapt their existing event management curricula to the new conditions. For example, the University of Surrey is one of the first to offer a postgraduate module on portfolio management. Indeed, the portfolio subject clearly needs to be embedded into the curriculum in order to prepare the future professionals with developing the outlook, skills and competencies for managing portfolios in a variety of contexts and environments. Furthermore, portfolio management needs to be linked and taught along with the other modules (e.g., operations, risk management, strategic management, policy, etc.) so that a grounded holistic mindset is developed. These changes are essential to keep in pace with the current trajectory of city and regional portfolio development. Therefore, the sooner the event-related epistemic community realizes the urgency for turning its attention on event portfolios the better integration can be achieved. 
Most of all, it should be realized that the emergence of the portfolio paradigm, presents opportunities for developing event specific theory, which can enhance the theoretical underpinnings of event-related studies and event management. Although the term portfolio is borrowed from financial portfolio theory, this does not mean that financial principles can be entirely applied to the events realm. Events are socio-cultural constructions and hence cannot be treated as financial assets, or even merely as commercial products. A holistic portfolio approach on events needs to find the means for balancing the social and economic value of different events, fostering synergies amongst them, garnering community support, solidifying stakeholder social networks, and implementing joint strategies (Ziakas, 2010, 2013, 2014a, 2014b; Ziakas \& Costa, 2010, 2011a, 2011b). In so doing, the development of event specific theory is necessary, which can help establish event management as an academic field and legitimize the event management profession.

\section{A Polemic}

This position paper commentary advocates for the pressing need to embrace more tenaciously and systematically the event portfolio paradigm in academic discourse and scholarship in order to accelerate knowledge creation on this emerging phenomenon. This requires substantial changes on how we view, study and deliver events. As has been pointed out, a policy change is widely evident in practice with cities and regions adopting multifarious portfolio approaches to develop their calendar events program. The proliferation of portfolios reveals the fact that the relationship between cities and events is changing to a more holistic place-making orientation that is intended to leverage multiple events for multiple purposes. Given the increasing complexity of this undertaking, the risks and challenges are elevated as multiple 
events bring in also multiple stakeholders with competing interests. Thus, the matter is to synchronize multiple goals amongst stakeholders and align them with the broad policy agenda of a host community as well as coordinate operationally joint actions and initiatives. Nonetheless, as so long academic attention on event portfolios lags behind, knowledge creation and dissemination are decelerated, which subsequently may inhibit their sustainable growth.

The argument for intensifying event portfolio research is based on a rationale of integration at conceptual, contextual, policy and operational levels. For example, the persistently common dichotomies of sport vs. arts, economic vs. social, or mega-events vs. small-scale events should be traversed. We need to develop knowledge how such a multi-level integration can be achieved and persistent divisions surpassed. Conceptual integration refers to the synthesis of different local viewpoints on events and their symbolic meanings within the local community. Contextual integration involves creating linkages for cross-institutional and interorganizational cooperation. Policy integration concerns the proportionately equal representation of purposes chosen to be pursued and the inclusive engagement of stakeholders in the policy-making process. Lastly, operational integration demands the establishment of governance schemes and management mechanisms to assemble an array of events and coordinate their implementation. The underlying intent is to create composite event portfolios that are versatile policy tools and have adaptive systemic properties. While unavoidably the resulting configurations of portfolio systems can vary in line with the particular development approaches employed, it is a fundamental axiom that they should all be grounded in local conditions and needs, encouraging resident engagement and support through their participation in portfolio planning and decision-making. To this end, processes of resident co-creation need to be adopted while facilitating a polyphony of viewpoints, ideas and meanings to be expressed. A portfolio thus can be viewed as a locally co-created polyphonic instrument that allows the 
expression and performance of different narratives that instantiate the foundational components of the host community and its relationship with the world.

At the same time, the complex nature of event portfolios brings to the fore serious challenges that need to be tackled. For example, the interference of political interests, uneven power structures and over-commercialization have deleterious impacts on events and may lead to a blurred strategic vision and direction, contentious stakeholder relationships and disengagement, resident opposition, lack of coordination and operational inefficiency, unequal distribution of portfolio benefits, and eventually loss of a portfolio's authenticity. The role of academics studying portfolios is to shed light on these challenges and develop appropriate responses as well as proactive mechanisms for the effective planning and management of event portfolios. There is a fertile and unexplored ground that needs to be cultivated carefully so that event portfolios fulfil their potential to the maximum. In brief, the following benefits can be derived from a well-managed portfolio (Ziakas, 2014a, pp. 184-85):

1. Hosting events throughout the year can sustain the impact of events as long as each event in the portfolio complements or reinforces the benefits bestowed by other events.

2. The variety of different events in a portfolio may target and reach diverse market segments, thus increasing the size of a host community's events market.

3. Different types of event in a portfolio may respond to different community issues (e.g. improving quality of life, building identity, promoting a healthy lifestyle, etc.) and reach varied segments of the population by appealing to people's different interests.

4. Different events, when bundled in a portfolio, can act as hooks for one another and thus bring together segments of the population that might not otherwise meet.

5. An event portfolio may unite in a network the event stakeholders of seemingly disparate events with the purpose of cross-leveraging them and thus may also foster collaboration.

6. An event portfolio may integrate different purposes in a comprehensive strategy and incorporate different events into a coherent whole that is more than the sum of its parts.

7. An event portfolio may help in the optimal use of a host community's integrated set of resources. 
On the whole, the event portfolio paradigm provides a comprehensive interdisciplinary framework for the synergistic study and management of planned events. This framework can provide the common ground for looking at particular areas, such as marketing, policy, operations, community and economic development, as well as tourism-related aspects. The range of applications can be as diverse as the purposes that event portfolios are employed to serve in a host community and a synergistic approach can help planners to effectively integrate portfolios as versatile tools in local development (Ziakas, 2018).

\section{Synopsis: Looking ahead}

As we are approaching ten years since the publication of the first research article studying the nature of an event portfolio, this commentary highlights the need for intensifying research and accelerating knowledge creation on this phenomenon. Especially, as portfolios currently move from infancy to adulthood, there is a lot to be learned about their effective planning and management. This knowledge can be profitably used to develop both an art and a science of portfolio expertise. Building such an intelligence within the realm of event management can help strengthen it as an academic field and advance the merits of the profession. The time that fruits will have grown to be ready for harvesting has yet to come; at the present, the fertile ground upon which the planted seed flourishes need to be carefully raised.

\section{References}

Andersson, T.D., Getz, D., \& Mykletun, R.J. (2013). The "Festival Size Pyramid" in three Norwegian festival populations. Journal of Convention and Event Tourism, 14(2), 81-103.

Andersson, T.D., Getz, D., Gration, D., \& Raciti, M.M. (2017). Event portfolios: Asset value, risk and returns. International Journal of Event and Festival Management, 8(3), 226-243. 
Antchak, V. (2017). Portfolio of major events in Auckland: Characteristics, perspectives and issues. Journal of Policy Research in Tourism, Leisure and Events, 9(3), 280-297.

Antchak, V., \& Pernecky, T. (2017). Major events programming in a city: Comparing three approaches to portfolio design. Event Management, 21(5), 545-561.

Auckland Council. (2011). Auckland's major events strategy. Auckland Tourism, Events and Economic Development Ltd. (ATEED). Retrieved from: http://www.aucklandnz.com/downloads/MajorEventsStrategy.pdf [Accessed on December 19, 2015].

City of Edinburgh. (2007). Inspiring events strategy. Retrieved from: http://eventsedinburgh.org.uk/files/documents/inspiring-events-strategy.pdf. [Accessed on December 19, 2015].

City of Gold Coast. (2011). Gold Coast city events strategic plan 2011-2015. Retrieved from: http://www.eventsgoldcoast.com.au/uploads/file/Gold-Coast-City-Events-Strategic-Plan2011-2015.pdf. [Accessed on December 19, 2015].

Clark, R., \& Misener, L. (2015). Understanding urban development through a sport events portfolio: A case study of London, Ontario. Journal of Sport Management, 29(1), 11-26.

Dickson, G., Milne, S., \& Werner, K. (2018). Collaborative capacity to develop an events portfolio within a small island development state: The Cook Islands. Journal of Policy Research in Tourism, Leisure and Events, 10(1), 69-89.

Dragin-Jensen, C., Schnittka, O., \& Arkil, C. (2016). More options do not always create perceived variety in life: Attracting new residents with quality- vs. quantity-oriented event portfolios. Cities, 55-62.

Getz, D. (2013). Event tourism: Concepts, international case studies, and research. New York: Cognizant.

Getz, D., \& Page, S. (2016). Event studies: Theory, research and policy for planned events (3 ${ }^{\text {rd }}$ edition). Abingdon: Routledge.

Gibson, H.J., Kaplanidou, K., \& Kang, S.J. (2012). Small-scale event sport tourism: A case study in sustainable tourism. Sport Management Review, 15(2), 160-170.

Gration, D., Raciti, M., Getz, D., \& Andersson, T.D. (2016). Resident valuation of planned events: An event portfolio pilot study. Event Management, 20(4), 607-622.

Kelly, D.M., \& Fairley, S. (2018). The utility of relationships in the creation and maintenance of an event portfolio. Marketing Intelligence and Planning, 36(2), 260-275.

Pereira, E.C.S., Mascarenhas, M.V.M., Flores, A.J.G., \& Pires, G.M.V.S. (2015). Nautical small-scale sports events portfolio: A strategic leveraging approach. European Sport Management Quarterly, 15(1), 27-47.

Presenza, A., \& Sheehan, L. (2013). Planning tourism through sporting events. International Journal of Event and Festival Management, 4(2), 125-139.

Richards, G. (2015). Events in the network society: The role of pulsar and iterative events. Event Management, 19(4), 553-566.

Sanders, D., Laing, J., \& Frost, W. (2015). Exploring the role and importance of post-disaster events in rural communities. Journal of Rural Studies, 41(1), 82-94. 
Taks, M., Chalip, L., Green, B.C., Kesenne, S., \& Martyn, S. (2009). Factors affecting repeat visitation and flow-on tourism as sources of event strategy sustainability. Journal of Sport and Tourism, 14(2/3), 121-142.

Viol, M., Todd, L., Theodoraki, E., \& Anastasiadou, C. (2018). The role of iconic-historic commemorative events in event tourism: Insights from the 20th and 25th anniversaries of the fall of the Berlin Wall. Tourism Management, 69, 246-262.

VisitScotland. (2015). Scotland the perfect stage: Scotland's events strategy 2015-2025. Retrieved from: http://www.eventscotland.org/assets/show/4658 [Accessed on April 14, 2017].

Welsh Government. (2010). Event Wales: A major events strategy for Wales 2010-2020. Retrieved from: http://gov.wales/topics/culture-tourism-sport/major-events/event-wales-amajor-events-strategy-for-wales-2010-2020/?lang=en [Accessed on April 14, 2017].

Westerbeek, H., \& Linley, M. (2012). Building city brands through sport events: Theoretical and empirical perspectives. Journal of Brand Strategy, 1(2), 193-205.

Ziakas, V. (2010). Understanding an event portfolio: The uncovering of interrelationships, synergies, and leveraging opportunities. Journal of Policy Research in Tourism, Leisure and Events, 2(2), 144-164.

Ziakas, V. (2013). A multi-dimensional investigation of a regional event portfolio: Advancing theory and praxis. Event Management, 17(1), 27-48.

Ziakas, V. (2014a). Event portfolio planning and management: A holistic approach. Abingdon: Routledge.

Ziakas, V. (2014b). Planning and leveraging event portfolios: Towards a holistic theory. Journal of Hospitality Marketing and Management, 23(3), 327-356.

Ziakas, V. (2018). Issues, patterns and strategies in the development of event portfolios: Configuring models, design and policy. Journal of Policy Research in Tourism, Leisure and Events, In Press, doi.org/10.1080/19407963.2018.1471481.

Ziakas, V., \& Boukas, N. (2016). The emergence of 'small-scale' sport events in 'small island' developing states: Towards creating sustainable outcomes for island communities. Event Management, 20(4), 537-563.

Ziakas, V., \& Costa, C.A. (2010). Explicating inter-organizational linkages of a host community's events network. International Journal of Event and Festival Management, 1(2), 132-147.

Ziakas, V., \& Costa, C.A. (2011a). The use of an event portfolio in regional community and tourism development: Creating synergy between sport and cultural events. Journal of Sport and Tourism, 16(2), 149-175.

Ziakas, V., \& Costa, C.A. (2011b). Event portfolio and multi-purpose development: Establishing the conceptual grounds. Sport Management Review, 14(4), 409-423. 